(ISSN - 2752-7018)

VOLUME 02 ISSUE 01 Pages: 100-105

SJIF IMPACT FACTOR (2021: 5. 376)

OCLC - 1276789625 METADATA IF - 7.569

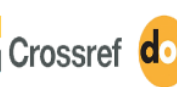

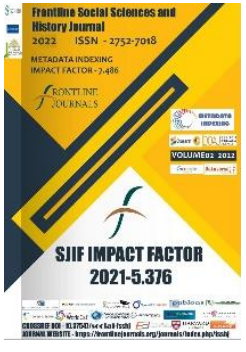

Journal Website: https://frontlinejournal s.org/journals/index.ph $\mathrm{p} /$ fsshj

Copyright: Original content from this work may be used under the terms of the creative commons attributes 4.0 licence.
Research Article

\section{SCYTHO-GERMANIC LEXICAL PARALLELS FROM THE FIRST VOLUME OF V.I. ABAEV'S "HISTORICAL AND ETYMOLOGICAL DICTIONARY"}

\author{
Submission Date: January 11, 2022, Accepted Date: January 20, 2022, \\ Published Date: January 31, 2022 \\ Crossref doi: https://doi.org/10.37547/social-fsshj-02-01-13 \\ Natalya Viktorovna Tyan \\ National University of Uzbekistan named after Mirzo Ulugbek, Uzbekistan,
}

\title{
Abstract
}
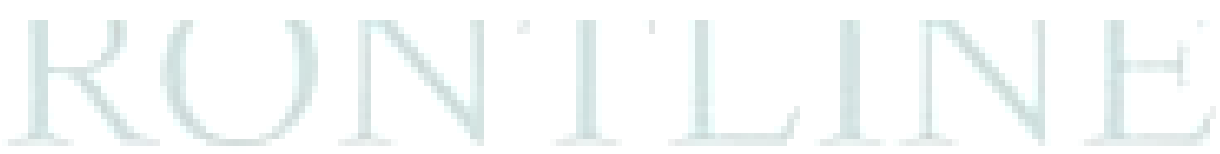

Since the term "Scytho-European/Germanic isogloss" is only found in the last three volumes, it makes sense to examine them more closely. A feature of the dictionary is that V.I. Abaev does not always use the terminology "Scytho-European" or "Scytho-Germanic isogloss" when describing vocabulary.

The fundamental "Historical and Etymological Dictionary of the Ossetian Language" in 4 volumes (1958 1989) is one of the main works of Doctor of Philology, Professor Abaev Vasily Ivanovich (Abaiti Vaso). It traces the etymology and history of Ossetian words, and the external relations of the Ossetian language with Indo-European and non-Indo-European languages

\section{KEYWORDS}

Historical and etymological dictionary, Professor Abaev Vasily Ivanovich, Abaiti Vaso, ScythoEuropean/Germanic isogloss. 


\section{INTRODUCTION}

The fundamental "Historical and Etymological Dictionary of the Ossetian Language" in 4 volumes (1958 - 1989) is one of the main works of Doctor of Philology, Professor Abaev Vasily Ivanovich (Abaiti Vaso). It traces the etymology and history of Ossetian words, and the external relations of the Ossetian language with IndoEuropean and non-Indo-European languages.

In the preface to the first volume, the author names the tasks, sources of factual and research material, describes the structure of the dictionary, as well as the features of transcription and spelling of the Ossetian language. Published texts in the Ossetian language, materials collected by V.I. Abaev and "Ossetian-Russian-German Dictionary" by V. Muller are given as sources.

\section{MaIn BodY}

Since the term "Scytho-European/Germanic isogloss" is only found in the last three volumes, it makes sense to examine them more closely. A feature of the dictionary is that V.I. Abaev does not always use the terminology "Scytho-European" or "Scytho-Germanic isogloss" when describing vocabulary. Very often there are such phrases as "coming closer to ...", "special semantic proximity to ...". This is sometimes confusing, as it is not always possible to be sure whether the author is referring to the isogloss or is simply giving a (semantic) parallel as an illustration. This is also found in his book "Scytho-European Isoglosses", where the author, giving parallels, means isoglosses.

It is noteworthy that the mention of "ScythoEuropean lexical isoglosses" is contained only in the last three volumes. In the first volume, on the contrary, this term does not occur, which is quite understandable. The vocabulary of the last three volumes, published between 1973 and 1989, was studied by V.I. Abaev more or less thoroughly from the standpoint of Ossetian-European contacts. A separate study of the ScythianEuropean isoglosses was reflected in his book "Scythian-European isoglosses", where, along with other isoglosses, a brief overview of nouns from among the German-Ossetian lexical parallels given in the first volume of V.I. Abaev's etymological dictionary is given [1].

The first volume of the "Historical and Etymological Dictionary of the Ossetian 
(ISSN - 2752-7018)

VOLUME 02 ISSUE 01 Pages: 100-105

SJIF IMPACT FACTOR (2021: 5. 376)

OCLC - 1276789625 METADATA IF -7.569

Language" was published in 1958. It contains a total of 172 lexical units (including verbs, adjectives and other parts of speech) that have grammatical, phonetic and lexical parallels in the Germanic languages. Our task is to identify from the total number of Scythian-European parallels given by the author of the dictionary, ScythoGermanic lexical parallels, i.e. those that can potentially be considered as Germano-Scythian lexical isoglosses.

In connection with the vastness of the material (172 dictionary entries), it became necessary to introduce certain restrictions.

We limited ourselves to nouns as words-names. At the same time, we focused on nouns in the Ossetian language, since the dictionary of the Ossetian language served as the source material. As a result, 97 nouns were identified. Further, the following words were eliminated from this number and were not taken into account in the analysis:

1. Lexical parallels that serve only as an illustration of a similar semantic development and therefore are not of interest in the study of Scytho-Germanic contacts (15 lexical units): oset. kærdæg 'grass'. The Ossetian word is built by V.I. Abaev to kærdyn 'to mow' as 'subject of mow'. As an example of a similar motivation for semantic development, the German heu 'hay' from hauen 'cut (down)'. By the same principle, the following words were excluded:

- oset. arv 'sky' from * abra 'cloud', fluctuating meaning as engl. sky, originally 'cloud';

- oset. æmygyr 'this is how each of the wives in relation to the other is called in case of polygamy', eng. co-wife;

- oset. ævdīsæn 'witness, testimony', also used in combinations ævdīsæn kænyn 'to renounce, refuse'. As an example of a similar development of meaning, V.I. Abaev cites germ. ver-zeihen 'forgive', ver-zichten 'refuse' from zeihen 'blame', originally 'show';

- oset. bæx 'horse', etc.

2. Lexical parallels that serve as an illustration of a similar word formation (6 lexical units): oset. dyvænd | duvændæ 'indecision, hesitation' is a combination of dy- 'two' and fænd 'intention' (literally 'doublethink') as in it. Zweifel 'doubt' from zwei 'two' [1,385]. For the same reasons, ætdor 'flint, tinderbox', fìdīs | fedes 'reproach', etc. 
(ISSN - 2752-7018)

VOLUME 02 ISSUE 01 Pages: 100-105

SJIF IMPACT FACTOR (2021: 5 376)

OCLC - 1276789625 METADATA IF -7.569

Publisher: Frontline Journals

3. Lexical parallels formed on the basis of onomatopoeia or sound symbolism (4 lexical units). This group also includes the so-called words of baby talk (3 units). They developed in different languages under similar conditions and for similar reasons independently of each other and therefore are similar in sound: oset. gakkuk | gakkok, guguk 'cuckoo' is of onomatopoeic origin, like German Kuckuck 'cuckoo' [1, 506]. The same applies to æda 'uncle, grandfather', æna 'mother, mother, grandmother', 3izi 'female breast', c'upp | c'opp 'top, top; wool, tuft', k'opp 'wooden bowl', k'ybyla | k'ibila 'tub, bucket; tub; bucket (wooden)'.

4. Germanic lexical parallels, where we are talking, first of all, about the interference between the Ossetian and Russian, Georgian and Turkic languages or about borrowings from these languages ( 9 lexical units). They are mentioned in dictionary entries only to show that they also occur in the Germanic languages or were borrowed from the Germanic languages in the listed languages: for example, oset. kartof 'potato' was borrowed from Russian, which in turn borrowed these words from German [1, 572]. By the same principle, they excluded armuk'a 'big market, fair' (from Russian 'yarmarka'), byran 'ferry' (from struss pram), gæræze 'coarse woolen fabric with warp and weft of different colors' (from Russian 'karazey'), koyf 'large basket' (from Türk. küfä 'wide open basket'), k'anzol 'camisole' (from Russian kamizol), etc. This also applies osset. koyrd | kurd 'blacksmith', which V.I. Abaev considers a Scythian-East Slavic lexical isogloss [1, 23].

5. Name Büræfærnyg | Boræfærnug as a proper name.

The following words were also excluded from the list:

6. oset. golf|gulf 'strong flow', 'strong wave', which is probably an accidental sound match with the European name of the bay (gr. кó $\lambda \pi$ s, germ. golf, eng. golf);

7. oset. boz, bozo, bozol 'goat', which has a reliable Iranian parallel: avest. būza-, pers. buz 'goat' and is of no interest for the study of Scythian-Germanic contacts;

8. and also osset. kom 'mouth', 'hole', where the Germanic parallels (English gōma, 
(ISSN - 2752-7018)

VOLUME 02 ISSUE 01 Pages: 100-105

SJIF IMPACT FACTOR (2021: 5 376)

OCLC - 1276789625 METADATA IF -7.569

Publisher: Frontline Journals

German gaumen 'sky') "apparently unrelated here" $[2,599]$. the future, each of these lexical units should be investigated from the point of view of etymology.

After the selection according to the above criteria, about 56 lexical units were subjected to a more thorough analysis.

\section{REFERENCES}

\section{Conclusion}

In the future, after a detailed analysis of the words, it was necessary to exclude from their number the vocabulary that goes back to IndoEuropean roots and that illustrates their common Indo-European origin in the Ossetian (Alanian) and Germanic languages. The Indo-European origin of most of these words is indicated by the author of the Historical and Etymological Dictionary of the Ossetian Dictionary. Common Indo-European parallels are important for establishing the kinship and degree of kinship of languages, but they are not of interest for the study of contacts.

After elimination, considering the last item, $23^{1}$ words remained that require further analysis. In
1. Abaev V.I. Scythian-European isoglosses at the junction of East and West. - M.: Nauka, 1965.

2. Abaev V. I. Historical and etymological dictionary of the Ossetian language. In 4 volumes. - M., L.: Ed. Academy of Sciences of the USSR. T. I, 1958.

3. Arabica, X. I. Proposals to review the works listed in this section (monographs as well as single articles) are invited by the publishers of LINGUISTICS. Abaev, VJ, Skifo-evropejskie izoglossy [ScythoEuropean Isoglosses]. Moscow, Nauka, 1965.166 pp. 64 kop.(" Postanovka problemy"[Stating the problem], 3-4;" Leksiceskie izoglossy"[Lexical isoglosses], 5-32;" Foneticeskie izoglossy.

\footnotetext{
${ }^{1}$ In the analysis of these words, dictionaries for individual languages were used, the list of which is given in the list of dictionaries and is not mentioned further.
} 
4. Blaškæ, G., \& Abaev, T. V. I. Wanderers and

Prophets in the Caucasus. Nartamongæ, 237.

5. Edzard, D. O. (1976). Colman-Gabriel Gostony: Dictionnaire d'étymologie sumérienne et grammaire comparée. xii, 204 pp. Paris: Éditions E. de Boccard, 1975. Bulletin of the School of Oriental and African Studies, 39(3), 637-638.

6. Ismatullaeva, N. R. (2020). Methods Of Elimination Of Lexical Gaps In Translation (on example of Chinese and Uzbek languages). Scientific Bulletin of Namangan State University, 2(10), 305314.

7. Thordarson, F. (1986). An Ossetic Miscellany Lexical Marginalia. NARTAMONGÆ, 281. 